\title{
PENGARUH KEBIJAKAN PEMERINTAH, PARTISIPASI MASYARAKAT DAN KEWIRAUSAHAAN TERHADAP KUALITAS DESTINASI WISATA PURA TAMAN AYUN
}

\author{
Made Indra Wibawa ${ }^{1}$ \\ I Gede Sudjana Budiasa ${ }^{2}$ \\ ${ }^{1,2,3}$ Fakultas Ekonomi dan Bisnis Universitas Udayana (Unud), Bali, Indonesia \\ Email : indra_jeep@yahoo.com
}

\begin{abstract}
ABSTRAK
Bali merupakan barometer pariwisata Indonesia, berbagai objek dan daya tarik wisata ditawarkan dari obyek wisata alam, wisata budaya dan minat khusus. Kekhasan budaya dan religinya mampu untuk memikat wisatawan datang dan kembali lagi ke Bali. Pariwisata budaya kini ditengarai sebagai salah satu segmen industri pariwisata yang perkembangannya paling cepat. Hal ini dilandasi oleh adanya kecenderungan atau trend baru di kalangan wisatawan untuk mencari sesuatu yang unik dan otentik dari suatu kebudayaan. Pariwisata budaya diyakini memiliki manfaat positif secara ekonomi dan sosial budaya. Jenis pariwisata ini dapat memberikan keuntungan ekonomi kepada masyarakat lokal. Pemberdayaan dan keterlibatan masyarakat dalam pengembangan pariwisata akan membuat masyarakat akan ikut berpartisipasi dalam menjaga budaya dan alam mereka sehingga pada akhirnya pembangunan pariwisata berkelanjutan akan tercapai. Semakin banyak masyarakat lokal mendapat manfaat dari tourism, maka semakin tinggi kepedulian mereka dalam rangka berpartisipasi menjaga dan memelihara konservasi alam, pelestarian budaya lokal serta secara aktif mengawal masa depan bisnis pelayanan pariwisata.

Kata kunci : Kebijakan pemeirntah, partisipasi masyarakat, kewirausahaan dankulitas destinasi wisata Pura Taman Ayun.
\end{abstract}

\begin{abstract}
Bali is a barometer of the Indonesian tourism, various objects and tourist attraction offered from natural tourism objects, cultural tourism and special interest. Cultural uniqueness and religinya capable to attract tourists to come and back again to Bali. Cultural Tourism is now considered as one of the industrial segment of tourism development most quickly. This is based on the existence of a new trend or tendency among tourists to find something unique and authentic from a culture. Cultural Tourism is believed to have the benefits of positive economic and social culture. The type of this tourism can provide economic benefits to local communities. The empowerment and community involvement in the development of the tourism will make the community will participate in maintaining the culture and nature them so that at the end of the development of sustainable tourism will be reached. The more local communities benefit from tourism, then the higher their concerns in order to participate to maintain and keep the nature conservation, preservation of local culture and actively control the future of the business tourism service. The goals in this research is to analyze the influence of government policy, community participation and entrepreneurship on the quality of the tourism destination Pura Taman Ayun.

Key Words : government policy, community participation, entrepreneurship and quality of tourism destination Pura Taman Ayun
\end{abstract}




\section{PENDAHULUAN}

Pariwisata merupakan salah satu industri terbesar dan tercepat di dunia yang mampu menghasilkan pertumbuhan ekonomi yang cepat terutama dalam penyediaan lapangan pekerjaan, peningkatan penghasilan, standar hidup serta stimulus bagi perkembangan sektor-sektor lainnya (Neto, 2000). Disamping itu tujuan jangka panjang yang diharapkan adalah guna memperoleh nilai-nilai ekonomi yang positif dimana pariwisata diharapkan dapat berfungsi sebagai katalisator dalam pengembangan perekonomian wilayah. Hal inilah yang menyebabkan daerah berlomba-lomba untuk memperkenalkan potensi pariwisata yang dimilikinya sehingga dapat menarik kunjungan wisatawan. Berkembangnya sektor pariwisata akan membawa dampak yang cukup besar pada industri-industri yang terkait seperti hotel, rumah makan, biro travel dan UKM di daerah-daerah kunjungan wisata karena dapat memproduksi dan menjual barang-barang cenderamata.

Dalam membentuk suatu destinasi wisata yang berkualitas maka sangat diperlukan adanya beberapa aspek yaitu: (1) atraksi (attraction) seperti pemandangan alam yang menarik, arsitektur, seni budaya, peninggalan sejarah dan seni pertunjukan; (2) aksesibilitas (accessibilities) seperti transportasi lokal serta telekomunikasi; (3) amenitas (amenities) seperti tersedianya akomodasi, rumah makan, dan agen perjalanan (Cooper et all, 1995). Serta adanya (4) ancilliary yaitu adanya sebuah organisasi atau orang-orang yang mengurus destinasi atau memberikan pelayanan wisata seperti pemandu wisata dan organisasi pengelola yang memiliki pengetahuan/pemahaman mengenai daerah 
tujuan wisata serta keramahan staf yang sangat berpengaruh dalam mendatangkan wisatawan (Holloway, 1985).

Bali merupakan barometer pariwisata Indonesia, berbagai objek dan daya tarik wisata ditawarkan yaitu dari obyek wisata alam, wisata budaya dan minat khusus. Bali dikenal sebagai salah satu destinasi pariwisata di Indonesia yang memiliki keunikan yang khas dibandingkan dengan destinasi-destinasi lainnya. Bali memiliki budaya sebagai atraksi unggulan, atraksi budaya maupun living culture adalah suatu hal tidak dapat dipisahkan dalam kehidupan sehari-hari masyarakat Bali. Warisan budaya yang masih mengakar kuat merupakan nilai tambah dalam menarik minat para wisatawan untuk datang dan berkunjung kembali lagi ke Bali.

Pariwisata budaya kini ditengarai sebagai salah satu segmen industri pariwisata yang perkembangannya paling cepat. Hal ini dilandasi oleh adanya kecenderungan atau trend baru di kalangan wisatawan untuk mencari sesuatu yang unik dan otentik dari suatu kebudayaan (Richards, 1997). Pariwisata budaya diyakini memiliki manfaat positif secara ekonomi dan sosial budaya, jenis pariwisata ini dapat memberikan keuntungan ekonomi kepada masyarakat lokal (Prayag et all, 2010). Pariwisata budaya juga mampu menghasilkan suatu interaksi yang positif antara masyarakat lokal dengan wisatawan sehingga menimbulkan suatu komunikasi dua arah. Hal lainnya yang harus dikembangkan adalah adanya ruang publik serta adanya infrastruktur yang baik dan memadai sehingga akan memberikan dampak positif bagi keberadaan obyek wisata (Kuvan and Akan, 2012) 
Peraturan Daerah (Perda) Provinsi Bali Nomor 2 Tahun 2012 tentang Kepariwisataan Budaya Bali menyebutkan bahwa pariwisata Bali diarahkan pada pariwisata budaya. Pariwisata budaya yang dimaksud adalah jenis kepariwisataan yang dalam perkembangan dan pengembangannya menggunakan kebudayaan daerah Bali yang dijiwai oleh agama hindu.

Salah satu wisata budaya di Bali adalah pura. Fungsi pura yang merupakan tempat religius sebagai tempat persembahyangan umat hindu di Bali juga merupakan daya tarik wisata. Struktur bangunan, sejarah, nilai religius melalui bentuk upacara ritual yang diselenggarakan di pura tersebut merupakan hal yang menarik bagi wisatawan untuk datang berkunjung.

Kabupaten Badung sangat dikenal sebagai salah satu tempat yang menawarkan berbagai macam destinasi wisata di Pulau Bali. Terdapat 36 jenis obyek wisata yang dimiliki oleh Kabupaten Badung yang menawarkan berbagai macam jenis wisata baik wisata alam, wisata budaya, wisata remaja, dan sebagainya. Hal ini dapat dilihat pada Tabel 1

Tabel 1

\section{Jumlah Obyek Wisata di Kabupaten Badung}

Tahun 2016

\begin{tabular}{clcl}
\hline NO & \multicolumn{1}{c}{ Nama Obyek Wisata } & Jenis Obyek wisata & Lokasi \\
\hline 1 & Kawasan Luar Pura Uluwatu & Wisata Budaya & Kuta Selatan \\
2 & Pantai Suluban & Wisata Alam & Kuta Selatan \\
3 & Pantai Nyang-Nyang & Wisata Alam & Kuta Selatan \\
4 & Pantai Padang-Padang & Wisata Alam & Kuta Selatan \\
5 & Pantai Labuan Sait & Wisata Alam & Kuta Selatan \\
6 & Pantai Batu Pageh & Wisata Alam & Kuta Selatan \\
7 & Pantai Samuh & Wisata Alam & Kuta Selatan \\
8 & Pantai Geger Sawangan & Wisata Alam & Kuta Selatan \\
9 & Pantai Nusa Dua & Wisata Alam & Kuta Selatan \\
10 & Pantai Tanjung Benoa & Wisata Alam & Kuta Selatan \\
11 & Pelestarian Penyu & Wisata Alam & Kuta Selatan \\
12 & Taman Rekreasi Hutan & Wisata Alam & Kuta Selatan \\
& Bakau & & \\
\hline
\end{tabular}




\begin{tabular}{|c|c|c|c|}
\hline 13 & Pantai Jimbaran & Wisata Alam & Kuta Selatan \\
\hline 14 & Garuda Wisnu Kencana & Wisata Budaya & Kuta Selatan \\
\hline 15 & Pantai Kedonganan & Wisata Alam & Kuta \\
\hline 16 & Pantai Kuta & Wisata Alam & Kuta \\
\hline 17 & Waterboom & Wisata Buatan & Kuta \\
\hline 18 & Pantai Legian & Wisata Alam & Kuta \\
\hline 19 & Pantai Petitenget & Wisata Alam & Kuta Utara \\
\hline 20 & Pantai Canggu & Wisata Alam & Kuta Utara \\
\hline 21 & Pantai seseh & Wisata Alam & Mengwi \\
\hline 22 & Pura Sada Kapal & Wisata Budaya & Mengwi \\
\hline 23 & $\begin{array}{l}\text { Kawasan Luar Pura Taman } \\
\text { Ayun }\end{array}$ & Wisata Budaya & Mengwi \\
\hline 24 & Desa Wisata Baha & Wisata Alam & Mengwi \\
\hline 25 & Bumi Perkemahan Blahkuih & Wisata Remaja & Abiansemal \\
\hline 26 & Alas Pala Sangeh & Wisata Alam & Abiansemal \\
\hline 27 & Tanah Wuk & Wisata Alam & Abiansemal \\
\hline 28 & Air Terjun Nungnung & Wisata Alam & Petang \\
\hline 29 & Wisata Agro Pelaga & Wisata Alam & Petang \\
\hline 30 & $\begin{array}{l}\text { Kawasan Luar Pura Pucak } \\
\text { Tedung }\end{array}$ & Wisata Budaya & Petang \\
\hline 31 & Pantai Berawa & Wisata Alam & Kuta Utara \\
\hline 32 & $\begin{array}{l}\text { Kawasan Pura Keraban } \\
\text { Langit }\end{array}$ & Wisata Budaya & Mengwi \\
\hline 33 & $\begin{array}{l}\text { Monumen Tragedi } \\
\text { Kemanusiaan }\end{array}$ & Wisata Budaya & Kuta \\
\hline 34 & Pantai Pandawa & Wisata Alam & Kuta Selatan \\
\hline 35 & $\begin{array}{l}\text { Kawasan Jembatan Tukad } \\
\text { Bangkung }\end{array}$ & Wisata Alam \& Buatan & Petang \\
\hline 36 & Bali Elephant Camp & Wisata Alam \& Satwa & Petang \\
\hline
\end{tabular}

Sumber : Badung dalam angka, 2016

Berdasarkan tabel 1 diatas, dapat dilihat bahwa di Kabupaten Badung terdapat 7 buah obyek wisata budaya yang masih eksis dan terus dijaga keberadaan, keasrian serta kelestariannya. Sektor pariwisata budaya juga terus dikembangkan dengan tujuan untuk mendapatkan tambahan pendapatan asli daerah sehingga dapat membantu dalam mewujudkan pembangunan di wilayah desa.

Berdasarkan Peraturan Daerah Kabupaten Badung Nomor 6 Tahun 2013 Tentang Rencana Tata Ruang Wilayah Kabupaten Badung Tahun 2013-2033 menyebutkan bahwa Kawasan Luar Pura Taman Ayun merupakan kawasan warisan budaya yang dipertegas dengan terbitnya Peraturan Bupati Badung No. 47 
Tahun 2010 Tentang Penetapan Kawasan Desa Wisata di Kabupaten Badung yang menyebutkan bahwa Kecamatan Mengwi ditetapkan sebagai wilayah pengembangan budaya yang diarahkan kepada pengembangan pariwisata minat khusus yang memiliki apresiasi terhadap seni dan budaya serta menjadikan aktifitas keseharian masyarakat desa sebagai daya tarik wisata.

Kecamatan Mengwi juga memiliki keunikan khusus yang relatif tidak dimiliki oleh kawasan destinasi wisata lain, yaitu fungsi Pura Taman Ayun sebagai pusat daya tarik wisata yang selama ratusan tahun telah memiliki peran sebagai pusat spiritual pertanian berbasis irigasi subak. Pura Taman Ayun merupakan salah satu pengembangan daya tarik wisata berbasis budaya yang terletak di Desa Mengwi, Kecamatan Mengwi Kabupaten Badung. Pura Taman Ayun ini adalah warisan budaya Bali yang memiliki arti sejarah penting dalam kehidupan masyarakat di sekitarnya. Kolam yang mengelilingi pura tidak hanya berfungsi estetika, namun berperan penting sebagai sumber irigasi bagi subaksubakyang berada di sekitarnya. Ini tidak terlepas dari adanya filosofi Tri Hita Karana (keharmonisan hubungan antara manusia dengan penciptanya, manusia dengan sesamanya serta manusia dengan lingkungannya) yang melandasi sistem pengairan subak.

Setelah ditetapkan sebagai Lanskap Budaya Bali pada tahun 2012, destinasi wisata Pura Taman Ayun mengalami kenaikan dalam jumlah kunjungannya. Dapat dilihat pada Tabel 2 
Tabel 2

Jumlah Kunjungan Wisatawan ke Pura Taman Ayun Tahun 2011-2015

\begin{tabular}{ccccccc}
\hline Tahun & Wisdom & $\%$ & Wisman & $\%$ & Jumlah & Pertumbuhan (\%) \\
\hline 2011 & 101.580 & & 110.838 & & 212.418 & \\
2012 & 62.058 & $(39)$ & 111.574 & 1 & 173.632 & $(18)$ \\
2013 & 76.376 & 23 & 205.525 & 84 & 281.901 & 62 \\
2014 & 83.751 & 10 & 245.940 & 20 & 329.691 & 17 \\
2015 & 95.873 & 14 & 267.634 & 9 & 363.507 & 10 \\
\hline
\end{tabular}

Sumber : Dinas Pariwisata Kab. Badung, 2016 (data diolah)

Pada Tabel 2 dapat dilihat bahwa jumlah kunjungan wisatawan ke Pura Taman Ayun secara umum adalah meningkat pasca ditetapkan oleh UNESCO, Kunjungan wisatawan didominasi oleh wisatawan mancanegara dengan jumlah kunjungan tertinggi sebesarnya 363.507 wisatawan, sedangkan kunjungan wisatawan domestik sebanyak 95.873 wisatawan pada tahun 2015. Penurunan kunjungan terjadi pada tahun 2012, hal ini disebabkan adanya proyek renovasi serta penataan jalan di depan kawasan Pura Taman Ayun. Jumlah kunjungan wisatawan yang cenderung meningkat ke destinasi wisata Pura Taman Ayun pada kenyataannya tidak diikuti oleh pertumbuhan jumlah usaha/jumlah masyarakat sekitar yang membuka lapangan pekerjaan (berwiraswasta), hal ini dapat dilihat pada Tabel 3

Tabel 3

Jumlah Penduduk Desa Mengwi Menurut Mata Pencaharian Tahun 2013-2015

\begin{tabular}{llccc}
\hline No & Jenis Pekerjaan & $\begin{array}{c}\text { Tahun 2013 } \\
\text { (orang) }\end{array}$ & $\begin{array}{c}\text { Tahun 2014 } \\
\text { (orang) }\end{array}$ & $\begin{array}{c}\text { Tahun 2015 } \\
\text { (orang) }\end{array}$ \\
\hline 1 & PNS & 619 & 620 & 634 \\
2 & Karyawan swasta & 1.235 & 1.224 & 1.075 \\
\hline
\end{tabular}




\begin{tabular}{llccc}
\hline 3 & Wiraswasta & 1.034 & 523 & 705 \\
4 & Petani & 361 & 407 & 350 \\
5 & Tukang/buruh & 1.381 & 1.402 & 1.052 \\
6 & Sopir & 38 & 38 & 34 \\
7 & Lain-lain & 400 & 499 & 551 \\
8 & Pensiunan & 141 & 135 & 152 \\
9 & Tidak/belum bekerja (anak-anak, & 2.323 & 2.726 & 3.198 \\
& pelajar, manula) & & \\
$\quad$ TOTAL & 7.532 & 7.574 & 7.599 \\
\hline
\end{tabular}

Sumber : Kantor Perbekel Desa Mengwi, 2016 (data diolah)

Berdasarkan Tabel 3 apabila dilihat secara persentasi jumlah partisipasi masyarakat dalam kegiatan berwiraswasta pada wilayah destinasi Pura Taman Ayun menunjukkan penurunan dari $15 \%$ kelompok wirausaha, menurun menjadi 7\% pada tahun 2014, dan tetap menurun dibandingkan dengan tahun 2013 turun menjadi $10 \%$. Penurunan kelompok mata pencaharian wirasusaha dapat di indikasikan sebagai pergeseran mata penaharian dari wirausaha ke mata pencaharian lainnya, hal ini mengindikasikan bahwa keberadaan destinasi wisata Pura Taman Ayun semakin menurunkan partisipasi masyarakat sekitar dalam upaya mendapatkan akses lapangan pekerjaan dan pembentukan pendapatan dari industri pariwisata tersebut. Pemberdayaan masyarakat akan menjadi kunci utama untuk pengembangan pariwisata karena dengan pemberdayaan dan keterlibatan masyarakat dalam pengembangan pariwisata, masyarakat akan memperoleh benefit serta ikut berpartisipasi dalam menjaga budaya dan alam mereka sehingga pada akhirnya pembangunan pariwisata akan tercapai. Semakin banyak masyarakat lokal mendapat manfaat dari tourism, maka semakin tinggi kepedulian mereka dalam rangka berpartisipasi menjaga dan memelihara konservasi alam, pelestarian budaya lokal serta turut serta secara aktif mengawal masa depan bisnis pelayanan pariwisata (Timothy, 2004). 
Meskipun demikian, tidaklah mudah mewujudkan bentuk partisipasi masyarakat untuk secara aktif dapat ikut serta dalam aktivitas pelayanan pariwisata. Tosun (2000) menyatakan terdapat community participation barrier sebagai komponen penggerak pada industri pariwisata, seperti lemahnya koordinasi, perencanaan pariwisata yang tidak memberi ruang kepada peran masyarakat lokal, serta adanya kendala dalam proses pengambilan keputusan yang menghambat akses masyarakat lokal dalam ikut serta menentukan arah kebijakan pengelolaan industri wisata (Gray, 2008)

Partisipasi masyarakat yang berbasis nilai tambah ekonomi diperankan oleh seberapa besar akses masyarakat lokal dapat berpartisipasi pada sektor industri pariwisata, sehingga kehadiran pariwisata dapat memberifikan benefit kepada masyarakat lokal yang diwujudkan dalam aktivitas terbukanya lapangan kerja dan pembentukan pendapatan masyarakat lokal berkaitan dengan kehadiran pariwisata tersebut. Makin banyak wisatawan yang berkunjung maka makin banyak pula jenis usaha yang tumbuh di daerah wisata, sehingga makin luas lapangan kerja yang tercipta.

Miler (1983) menyatakan terdapat tiga dimensi sikap yang dapat menjadi penentu dalam mendorong kreativitas dan inovasi pada sektor bisnis yaitu, (a) sikap risk-taking, yang dicerminkan oleh perilaku masyarakat yang memiliki keberanian untuk menghadapi resiko bisnis. (b) sikap proactive yang ditunjukkan oleh perilaku dalam membangun kreativitas dan inovasi dalam upaya mendapatkan segmentasi pangsa pasar yang lebih luas, serta (c) adalah sikap responsive dinyatakan sebagai sikap perilaku tanggap terhadap barang dan jasa 
yang diinginkan oleh perkembangan pasar konsumen. Terakhir perlu adanya (d) sikap autonomy, yang merupakan sikap kemandirian tidak tergantung kepada pihak lain dalam membangun kreativitas dan inovasi (Calvin dan Slevin, 2011).

Dalam rangka pengembangan sebuah destinasi wisata, disamping adanya peran aktif dari dukungan lingkungan masyarakat dan potensi kewirausahaan, juga perlu adanya dukungan kebijakan pemerintah yang memegang peran yang sangat strategis. Pemerintah harus memiliki tanggung jawab dalam pembangunan pariwisata dengan cara menempatkan pariwisata sebagai green industry (industri ramah lingkungan). Connel et al (2009) menyatakan pemerintah berperan untuk mengkondisikan ketertiban dan keamanan masyarakat, penataan regulasi tata ruang, dan pengembangan perencanaan pariwisata. Dalam rangka pengembangan destinasi wisata di sebuah kawasan tertentu, pemerintah lebih banyak berperan dalam penyediaan pendanaan, seperti pembangunan museum, gallery, taman rekreasi, serta penyediaan infrastruktur dan seterusnya.

Kebijakan pemerintah juga dapat menjadi penentu di dalam pengembangan inovasi bagi usaha kecil dan menengah (Cook et all, 2003) serta dapat menjadi pengendali arah perkembangan inovasi yang akan memiliki dampak terhadap keberlanjutan usaha kecil dan menengah, konsumen serta pelayanan publik lainnya (Herrena dan Nieto, 2008). Selain itu Pemerintah juga berperan antara lain, (1) mendorong pengembangan inovasi perusahaan, (2) memberikan bantuan finansial, (3) regulasi untuk memproteksi usaha, (4) kebijakan pemberdayaan (Mustar and Laredo, 2002). 
Kebijakan pemerintah sangat berperan dalam mendorong perkembangan pariwisata, dalam kaitan ini baik pemerintah provinsi maupun kabupaten/kota membuat kebijakan yang mampu untuk mendorong perkembangan pariwisata serta meningkatkan aktivitas pariwisata. Kebijakan-kebijakan yang diambil oleh Pemerintah Daerah dalam hal ini Pemerintah Daerah Kabupaten Badung terhadap destinasi wisata Pura Taman Ayun diantaranya adalah menerbitkan Peraturan Daerah (Perda) Nomor 6 Tahun 2013 tentang Rencana Tata Ruang Wilayah (RTRW) Kabupaten Badung dimana wilayah Badung Tengah ditetapkan sebagai wilayah pertanian berkelanjutan dan Ibu Kota Kabupaten Badung yaitu Mangupura sebagai pusat kegiatan sosial-budaya dan kesenian sehingga terdapat unsur-unsur melindungi, merevitalisasi, rehabilitasi, preservasi dan/atau restorasi warisan budaya yang memiliki nilai-nilai sejarah yang didalamnya terdapat tempat Kawasan Daya Tarik Wisata Khusus (KDTWK).

Berkenaan dengan hal tersebut Pemerintah Kabupaten Badung telah melakukan penataan dan perbaikan sarana dan prasarana yang ada di kawasan luar Pura Taman Ayun seperti pembuatan pedestrian, pembuatan candi kurung, penataan parkir, penataan pedagang serta menata kolam yang mengelilingi Pura Taman Ayun, sedangkan pada kawasan dalam Pura Taman Ayun telah dilakukan perbaikan fisik seperti perbaikan fasilitas toilet, candi bentar, perbaikan wantilan dan lain-lain sehingga menjadi tetap bersih, asri, lestari dan aman. Hal ini membuktikan bahwa destinasi wisata yang berkualitas tidak saja dibentuk melalui partisipasi masyarakat dan potensi kewirausahaan tetapi perlu adanya campur tangan pemerintah. 


\section{Rumusan Pokok Masalah}

1. Bagaimana pengaruh secara langsung kebijakan pemerintah, partisipasi masyarakat dan kewirausahaan terhadap kualitas destinasi wisata Pura Taman Ayun ?

2. Bagaimana pengaruh secara langsung kebijakan pemerintah dan partisipasi masyarakat terhadap kewirausahaan?

3. Apakah kebijakan pemerintah dan partisipasi masyarakat secara tidak langsung berpengaruh terhadap kualitas destinasi wisata Pura Taman Ayun melalui kewirausahaan?

\section{Partisipasi Masyarakat}

Conyers (1991) menyampaikan terdapat tiga alasan utama pentingnya partisipasi masyarakat dalam pembangunan, yaitu: (1) partisipasi masyarakat merupakan suatu alat guna memperoleh informasi mengenai kondisi, kebutuhan dan sikap masyarakat setempat, yang tanpa kehadirannya program pembangunan dan proyek akan gagal, (2) masyarakat mempercayai program pembagunan jika dilibatkan dalam proses persiapan dan perencanaannya, karena masyarakat lebih mengetahui seluk beluk proyek dan merasa memiliki proyek tersebut, (3) partisipasi merupakan hak demokrasi masyarakat dalam keterlibatannya di pembangunan.

Partisipasi masyarakat merupakan bagian yang sangat strategis dalam pengembangan industri pariwisata. Bopp et all (2000), mendefinisikan partisipasi komunitas pada industri pariwisata sebagai kualitas dari komunikasi antar individu yang memberikan ruang kepada semua pihak termasuk wisatawan untuk 
hidup bersama secara harmonis. Menurut Syahyuti (2005), partisipasi adalah proses tumbuhnya kesadaran terhadap kesalinghubungan di antara stakeholders yang berbeda dalam masyarakat, yaitu antara kelompok-kelompok sosial dan komunitas dengan pengambil kebijakan dan lembaga-lembaga jasa lain. Partisipasi didefinisikan sebagai proses dimana seluruh pihak dapat membentuk dan terlibat dalam seluruh inisiatif pembangunan. Oleh sebab itu pembangunan yang partisipatif merupakan pembangunan yang melibatkan peran aktif masyarakat dalam seluruh keputusan substansial yang berkenaan dengan kehidupan mereka. Secara harfiah, partisipasi dapat diartikan sebagai ikut sertanya seseorang atau kelompok dalam suatu kegiatan tertentu. Sedangkan partisipasi warga adalah suatu bentuk keikutsertaan langsung warga dalam pembuatan kebijakan dan pengambilan keputusan yang mempengaruhi kehidupan mereka (Suhirman, 2004).

\section{Kewirausahaan}

Gagasan teoritik tentang pentingnya perilaku kreatif dan inovatif dalam pengembangan kegiatan usaha digagas oleh Miler (1983) yang telah menjadi inti pustaka sampai saat ini sebagai kerangka pendekatan dalam pengembangan kreativitas dan inovasi. Sikap yang dapat menjadi penentu untuk mendorong kreativitas dan inovasi dirumuskan sebagai sikap risk-taking, sikap proactive serta sikap responsive, ketiganya merupakan dimensi keperilakuan yang menggambarkan sikap dan perilaku kewirausahaan.

Calvin dan Slevin (2011) menyatakan perlunya memperluas sikap wirausahawan sebagai perilaku yang mandiri dalam membangun kreativitas dan 
inovasi, sehingga perilaku kewirausahawan dapat diperluas menjadi empat dimensi yaitu sikap risk-taking, proactive, responsive dan autonomy (kemandirian). Konsep teori perilaku kewirausahawan juga dikembangkan oleh Baldacchini (2009) yang menyatakan bahwa wiraswasta harus memiliki sikap kreatif dan inovatif dalam mengembangkan usahanya sehingga menjadi lebih bersaing. Sikap ini perlu dikembangkan oleh wiraswasta karena kebutuhan, keinginan, dan permintaan konsumen yang selalu berubah-ubah (Larsen, $\mathrm{P}$ and Lewis, A, 2007). Untuk itu diharapkan dengan adanya sikap dan perilaku kreatif dan inovatif yang dimiliki oleh masyarakat lokal dapat menjadi faktor penting dalam keberhasilan mewujudkan pariwisata yang berkualitas (Hall \& Williams, 2008).

\section{Kebijakan Pemerintah}

Pemerintah memiliki lima fungsi utama diantaranya: (1) sebagai penyedia layanan, yaitu fungsi-fungsi pemerintah yang berkaitan dengan penyediaan pelayanan yang berorientasi pada lingkungan dan masyarakatnya. (2) fungsi pengaturan, yaitu fungsi yang berkaitan dengan perumusan dan penegakkan peraturan-peraturan. (3) fungsi pembangunan yaitu fungsi yang berkaitan dengan keterlibatan pemerintah dalam kegiatan ekonomi. (4) fungsi perwakilan yaitu mewakili masyarakat di luar wilayah mereka. (5) fungsi koordinasi yaitu berkaitan dengan peran pemerintah dalam pengkoordinasiaan, perencanaan, investasi dan tata guna lahan (Davey, 1998).

Peranan pemerintah dalam mengembangkan pariwisata dalam garis besarnya, adalah (1) menyediakan infirastuktur (tidak hanya dalam bentuk fisik), 
(2) memperluas berbagai bentuk fasilitas, (3) kegiatan koordinasi antara aparatur pemerintah dengan pihak swasta, (4) pengaturan dan promosi umum, (5) sarana transportasi, (6) keadaan infrastruktur dan sarana-sarana pariwisata.

\section{Partisipasi Masyarakat Dalam Pengembangan Pariwisata}

Masyarakat lokal, terutama penduduk asli yang bermukim di kawasan wisata menjadi salah satu pemain kunci dalam pariwisata, karena sesungguhnya merekalah yang akan menyediakan sebagian besar atraksi sekaligus menentukan kualitas produk wisata. Jamal dan Getz (2005) menyatakan apabila masyarakat lokal mendapatkan sharing benefits dari keberadaan industri pariwisata, maka masyarakat akan dapat mengembangkan partisipasinya dalam proses kegiatan industri dan pelayanan kepariwisataan. Dukungan partisipasi masyarakat diperlukan karena akan menciptakan nilai tambah pelayanan pariwisata, serta ikut aktif berpartisipasi melestarikan obyek wisata, lingkungan alam serta mencegah potensi konflik yag terjadi sebagai akibat dari keberadaan pariwisata yang selalu berdampak pada lingkungan dan beban sumber daya alam sebagai akibat dari aktivitas pariwisata.

\section{Peran Pemerintah Dalam Pengembangan Pariwisata}

Beberapa peran yang mutlak menjadi tanggung jawab pemerintah menurut Damanik dan Weber (2006) adalah sebagai berikut:

1) Penegasan dan konsistensi tentang tata guna lahan untuk pengembangan kawasan wisata, termasuk kepastian hak kepemilikan, sistem persewaan dan sebagainya. 
2) Perlindungan lingkungan alam dan cagar budaya untuk mempertanyakan daya tarik objek wisata, termasuk aturan pemanfaata sumberdaya lingkungan tersebut.

3) Penyediaan infrastruktur (jalan, pelabuhan, bandara dan angkutan pariwisata).

4) Fasilitas fiskal, pajak, kredit, dan ijin usaha yang tidak rumit agar masyarakat lebih terdorong untuk melakukan wisata dan usaha-usaha kepariwisataan semakin cepat berkembang.

5) Keamanan dan kenyamanan berwisata melalui penugasan polisi khusus pariwisata dikawasan-kawasan wisata dan uji kelayakan fasilitas wisata (kendaraan, jalan dan lain-lain).

6) Jaminan kesehatan di daerah tujuan wisata melalui sertifikasi kualitas lingkungan dan mutu barang yang digunakan wisatawan.

7) Penguatan kelembagaan pariwisata dengan cara memfasilitasi perluasan jaringan kelompok dan organisasi kepariwisataan.

8) Pendampingan dalam promosi wisata, yakni perluasan dan intensifikasi jejaring kegiatan promosi di dalam dan luar negeri.

9) Regulasi persaingan usaha yang memungkinkan kesempatan yang sama bagi semua orang untuk berusaha di sektor pariwisata, melindungi UKM wisata, mencegah perang tarif, dan sebagainya.

10) Pengembangan sumber daya manusia dengan menerapkan sistem sertifikasi kompetensi tenaga kerja pariwisata dan akreditasi lembaga pendidikan pariwisata. 


\section{METODE PENELITIAN}

Metode penelitian yang digunakan dalam penelitian ini adalah kuantitatif, menggunakan data primer yang diperoleh dari responden menggunakan kuisioner.

Populasi dalam penelitian ini sebanyak 705 orang yang merupakan penduduk dari Desa Mengwi yang bermata pencaharian di bidang wirausaha. Sedangkan jumlah sampelnya adalah sebanyak 88 orang. Lokasi penelitian adalah di Desa Mengwi, Kecamatan Mengwi Kabupaten Badung. Fokus penelitian ini adalah untuk mengetahui bagaimana persepsi masyarakat yang sekaligus sebagai wirausaha dalam membentuk kualitas destinasi wisata Pura Taman Ayun.

Dalam penelitian ini terdapat 2 variabel bebas (independen variable) yaitu kebijakan pemerintah dan partisipasi masyarakat, sebuah variable terikat (dependen variable) yaitu kualitas destinasi wisata Pura Taman Ayun serta sebuah variable perantara (intervening variable) yaitu kewirausahaan.

Definisi operasional masing-masing variabel yang diteliti adalah sebagai berikut:

1. Kebijakan pemerintah (X1) adalah bentuk kebijakan yang telah dilakukan oleh Pemerintah Daerah Kabupaten Badung terhadap destinasi wisata Pura Taman Ayun dengan tujuan untuk meningkatkan kualitas destinasi wisata. Dengan indikator yaitu promosi, sarana dan prasarana, pelatihan dan pemberdayaan dan regulasi

2. Partisipasi masyarakat (X2) adalah sejauh mana keterlibatan masyarakat sebagai pendukung keberadaan destinasi wisata Pura Taman Ayun dapat memberikan manfaat ekonomi. Dengan indicator yaitu kesempatan kerja, peningkatan 
pendapatan masyarakat, pelestarian lingkungan, pengambilan keputusan serta dampak pariwisata terhadap budaya lokal.

3. Kewirausahaan (Y1) adalah sejauh mana kehadiran destinasi wisata Pura Taman Ayun dapat mendorong kreativitas dan inovasi pada sektor bisnis bagi masyarakat. Variabel ini diukur dengan indikator-indikator sebagai berikut risk taking, proactive, responsive dan autonomy.

4. Kualitas destinasi wisata Pura Taman Ayun (Y2) adalah bagaimanakah kualitas destinasi wisata Pura Taman Ayun. Variabel ini dengan indikatorindikator sebagai berikut daya tarik, aksesibilitas, organisasi pendukung, transparansi dalam informasi dan perdagangan.

Gambar 1.

Kerangka Konsep Penelitian

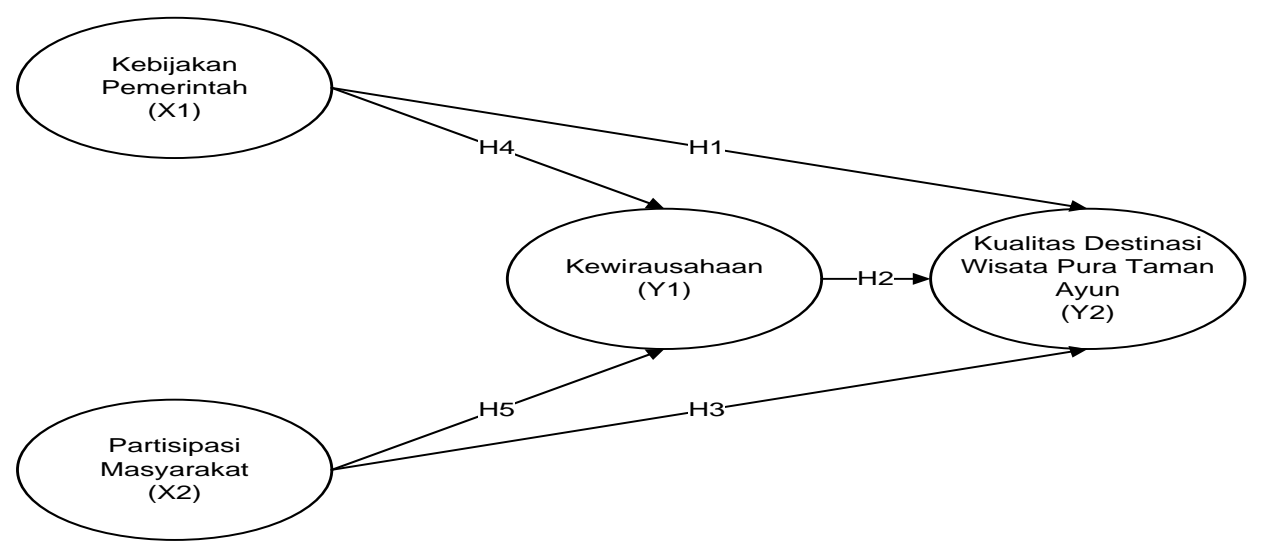

Konsep penelitian berangkat dari teori pembangunan pariwisata berkelanjutan. Menurut Cox dalam Dowling dan Fannel (2003), pembentukan pariwisata yang berkualitas harus memperhatikan prinsip-prinsip dimana pembangunan dan pengembangan pariwisata harus berdasarkan pada kearifan lokal, dimana partisipasi masyarakat diperlukan untuk mendukung terjaganya 
budaya dan adat istiadat di Pura Taman Ayun yang didukung oleh kebijakan pemerintah.

Pembangunan pariwisata harus berlandaskan pada upaya pemberdayaan, baik dalam arti ekonomi, sosial, maupun cultural yang merupakan suatu model pariwisata yang mampu merangsang tumbuhnya kualitas sosio-kultural dan ekonomi masyarakat serta menjamin kelestarian lingkungan. Selain itu untuk membangun suatu pariwisata yang berkualitas harus memperhatikan beberapa komponen yaitu : (1) atraksi (attraction) seperti pemandangan alam yang menarik, arsitektur, seni budaya, peninggalan sejarah dan seni pertunjukan; (2) aksesibilitas (accessibilities) seperti transportasi lokal serta telekomunikasi; (3) amenitas (amenities) seperti tersedianya akomodasi, rumah makan, dan agen perjalanan (Cooper et all, 1995). Serta adanya (4) ancilliary yaitu adanya sebuah organisasi atau orang-orang yang mengurus destinasi atau memberikan pelayanan wisata sepetri pemandu wisata dan organisasi pengelola (Holloway, 1998)

Data yang telah terkumpul akan diolah dengan menggunakan teknik analisis statitistik deskriptif dan teknik analisis persamaan struktural (SEM) dengan alternatif Partial Least Square (PLS) (component based SEM). Terakhir, dilakukan interpretasi masing-masing variabel untuk melihat kesesuaian model teoritik dan empirik sehingga dapat ditarik kesimpulan dari rumusan masalah penelitian.

\section{HASIL DAN PEMBAHASAN}

Pengujian tingkat reliabilitas instrument penelitian dilakukan dengan prosedur cronbach, sedangkan untuk melakukan uji terhadap validitas instrument 
dilakukan dengan mempergunakan prosedur uji KMO, kedua metode pengujian tersebut diperoleh melalui bantuan paket Soaftware SPSS. Hasil pengolahan data untuk uji reliabilitas dan uji validitas disajikan pada Tabel 4.

Tabel 4

Hasil Uji Instrumen Penelitian

Reliabilitas dan Validitas Untuk 80 Responden

\begin{tabular}{ccccl}
\hline Dimensi & $\begin{array}{c}\text { Cronbach's } \\
\text { Alpha }\end{array}$ & Ket. & $\begin{array}{c}\text { Nilai KMO } \\
\text { MSA }\end{array}$ & Ket. \\
\hline X1 & 0.912 & Reliabel & 0.729 & Valid. \\
X2 & 0.871 & Reliabel & 0.764 & Valid. \\
Y1 & 0.946 & Reliabel & 0.815 & Valid. \\
Y2 & 0.903 & Reliabel & 0.872 & Valid. \\
\hline
\end{tabular}

Sumber : Hasil penelitian

Penelitian ini mempergunakan uji statistik cronbach Alpha yaitu untuk melihat konsistensi internal dengan upaya melakukan pengujian untuk mendapatkan penilaian atas kondisi inter-item correlation dari indikator yang merefleksikan bahwa konstruk telah memiliki sebaran nilai yang konsisten dinyatakan sebagai reliabilitas instrumen apabila nilai cronbach alpha adalah minimal 0.70. Berdasarkan sebaran nilai cronbach alpha diatas 0.70 , sehingga semua konstruk yang disertakan pada penelitian ini dinyatakan reliable.

Penelitian ini mempergunakan software SmartPls versi 3.2.6 sebagai pendukung untuk mendapatkan hasil analisis outer-model untuk mengukur pada tingkat pertama posisi relasi antara konstruk dengan indikatornya. Pengujian tahap pertama, adalah untuk mengevaluasi tingkat reliabilitas instrumen penelitian berdasarkan tiga prosedur pengujian yaitu (a) cronbach Alpha, (b) composite reliability serta (d) convergence validity melalui sebaran nilai AVE. Ketiga komponen pengujian disajikan pada table 5 . 
Tabel 5

Hasil Uji Reliabilitas Penelitian

\begin{tabular}{lccc}
\hline \multicolumn{1}{c}{ Indikator } & Cronbach Alpha & C.R & AVE \\
\hline Kebijakan Pemerintah (X1) & 0.832 & 0.888 & 0.667 \\
Partisipasi Masyarakat (X2) & 0.907 & 0.928 & 0.683 \\
Kewirausahaan (Y1) & 0.877 & 0.915 & 0.730 \\
Kualitas Destinasi Wisata Pura Taman & 0.917 & 0.941 & 0.801 \\
Ayun (Y2) & & & \\
\hline Sumber: Hasil Penelitian & &
\end{tabular}

Sumber : Hasil Penelitian

Berdasarkan Tabel 5 didapatkan sebaran nilai cronbach Alpha diatas 0.70 untuk semua konstruk penelitian ini. Hair et al (2010) menyatakan bahwa nilai cronbach Alpha diatas 0.70 adalah memilki syarat sebagai konstruk penelitian yang reliable. sehingga dapat disimpulkan bahwa semua instrumen yang dipergunakan penelitian ini adalah reliable.

Menganalisis secara terpisah kedua variabel dependen itu diperlukan untuk memastikan peran yang ditunjukkan oleh variable dependent berikutnya, selain dari variabel dependen dari persamaan awal. Hal ini dilakukan untuk melakukan evaluasi apakah terdapat peluang dependent variable berikutnya dalam memperjelas model penelitian menjadi lebih kuat, memadai atau lemah (Cohen, 1988).

Berdasarkan Tabel 6 dapat dinyatakan bahwa dependent variable kewirausahaan (Y1) dengan nilai $\mathrm{R}^{2}=0.612$, serta konstruk kualitas destinasi wisata Pura Taman Ayun sebagai variable dependen (Y2), dengan nilai $\mathrm{R}^{2}=0.695$ tercatat lebih tinggi dibandingkan dependent variable kewirausahaan (Y1). Jika dibandingkan dengan sebaran nilai $\mathrm{R}^{2}$ dan $\mathrm{R}^{2}$ Adjusted, maka tampak bahwa sebaran nilai $\mathrm{R}^{2}$ dari $\mathrm{Y} 1$ dan $\mathrm{Y} 2$ masih lebih besar dibandingkan dengan sebaran nilai $\mathrm{R}^{2}$ Adjusted untuk dua konstruk bersangkutan. Sehingga dapat disimpulkan 
bahwa penambahan konstruk masih dimungkinkan dimasa depan, hal yang searah dengan temuan nilai $\mathrm{R}^{2}$ yang masih dapat ditingkatkan lebih banyak variabel eksogen untuk meningkatkan lebih banyak variasi nilai menjadi lebih tinggi dari kedua nilai $\mathrm{R}^{2}$ tersebut.

Tabel 6

Sebaran Nilai $\mathrm{R}^{2}$ dan $\mathrm{R}^{2}$ adjusted

\begin{tabular}{lccc}
\hline & R Square & $\begin{array}{c}\text { R Square } \\
\text { Adjusted }\end{array}$ & Keterangan \\
\hline $\begin{array}{l}\text { Kewirausahaan (Y1) } \\
\begin{array}{l}\text { Kualitas Destinasi Wisata Pura } \\
\text { Taman Ayun (Y2) }\end{array}\end{array}$ & 0.612 & 0.602 & Memadai \\
\hline Sumber: Data penelitian & 0.695 & 0.683 & Kuat \\
\hline
\end{tabular}

Berdasarkan Tabel 7, ternyata didapatkan dari sebanyak lima tujuan penelitian yang disusun sebaga relasi direct effect, didapatkan sebanyak dua hipotesis yang tidak signifikan dengan P-value lebih besar dari 5\%

Tabel 7

Hasil Analisis Path Coefficient Dan Signifikasi

\begin{tabular}{cccccl}
\hline & $\begin{array}{c}\text { Original } \\
\text { Sample } \\
(\mathbf{O})\end{array}$ & $\begin{array}{c}\text { Standard } \\
\text { Deviation } \\
(\text { STDEV) }\end{array}$ & $\begin{array}{c}\text { T Statistics } \\
(\mid \mathbf{O} / \text { STDEV })\end{array}$ & P Values & Keterangan \\
\hline$(\mathrm{X} 1) \rightarrow(\mathrm{Y} 1)$ & 0.325 & 0.119 & 2.733 & 0.006 & Signifikan \\
$(\mathrm{X} 1) \rightarrow(\mathrm{Y} 2)$ & 0.117 & 0.068 & 1.733 & 0.084 & Tdk signifikan \\
$(\mathrm{X} 2) \rightarrow(\mathrm{Y} 1)$ & 0.550 & 0.112 & 4.892 & 0.000 & Signifikan \\
$(\mathrm{X} 2) \rightarrow(\mathrm{Y} 2)$ & 0.015 & 0.093 & 0.165 & 0.869 & Tdk signifikan \\
$(\mathrm{Y} 1) \rightarrow(\mathrm{Y} 2)$ & 0.742 & 0.103 & 7.212 & 0.000 & Signifikan \\
\hline
\end{tabular}

Sumber : Data Penelitian

Berdasarkan tabel 8 dapat dilihat penelusuran terhadap peran mediasi ternyata menunjukkan relasi yang signifikan, yaitu hubungan tidak langsung dari kebijakan pemerintah (X1) terhadap kualitas destinasi wisata Pura Taman Ayun (Y2) melalui kewirausahaan (Y1) adalah signifikan, hal yang juga searah didapatkan pada relasi mediasi dari partisipasi masyarakat (X2) yang berpengaruh 
secara tidak langsung terhadap kualitas destinasi wisata Pura Taman Ayun (Y2) kewirausahaan (Y1) adalah signifikan.

Tabel 8

Hasil Analisis Signifikansi Indirect Effect

\begin{tabular}{|c|c|c|c|c|c|}
\hline Konstruk & & $\begin{array}{l}\text { Original } \\
\text { Sample }\end{array}$ & T Statistics & P Values & Keterangan \\
\hline (X1) & $\rightarrow \quad(\mathrm{Y} 2)$ & 0.241 & 2.640 & 0.009 & Mediasi Penuh \\
\hline \multicolumn{6}{|l|}{ Melalui Y1 } \\
\hline (X2) & $\rightarrow \quad(\mathrm{Y} 2)$ & 0.409 & 4.065 & 0.000 & Mediasi Penuh \\
\hline
\end{tabular}

Melalui Y1

Sumber : Data Penelitian

Berdasarkan Tabel 8 maka dapat diinterprestasikan hasil analisis sebagai berikut:

1. Besarnya koefisien estimasi dari kebijakan pemerintah (X1) terhadap kewirausahaan (Y1) adalah 0.325. Koefisien tersebut bertanda positif yang artinya semakin banyak kebijakan yang dikeluarkan pemerintah maka semakin tinggi pertumbuhan kewirausahaan (Y1) masyarakat lokal. Dan sebaliknya semakin sedikit kebijakan yang dikeluarkan pemerintah maka semakin rendah pula pertumbuhan kewirausahaan (Y1) masyarakat lokal. Hasil ini didukung oleh penelitian yang dilakukan oleh Shuo (2014) yang menyajikan bukti empirik bahwa kebijakan pemerintah telah diarahkan sepenuhnya untuk memberikan fasilitas subsidi, insentif perpajakan serta pembiayaan dalam rangka pengembangan sumber daya manusia membangun entrepreneuship yanag dapat lebih menjamin percepatan pembangunan.

2. Besarnya koesifien estimate dari partisipasi masyarakat (X2) terhadap kewirausahaan (Y1) adalah 0.550. Koefisien tersebut bertanda positif yang apabila partisipasi masyarakat (X2) semakin ditingkatkan maka semakin 
besar pula pertumbuhan kewirausahaan (Y1) masyarakat lokal. Hal ini sejalan dengan penelitian yang dilakukan oleh Bratt and Fainstein (2008) mendapatkan fakta empirik bahwa partisipasi masyarakat menjadi komponen penggerak terbukanya pertukaran informasi untuk membangun entrepreneur. Masyarakat akan mendapatkan keuntungan melalui kewiraswastaan termasuk mendorong pertumbuhan ekonomi dengan mengarah pada peningkatan pendapatan, peningkatan taraf hidup, peningkatan peluang investasi, pengembangan teknologi, pengembangan keterampilan, dan penciptaan kesempatan kerja.

3. Besarnya koesifien estimate dari kebijakan pemerintah (X1) terhadap kualitas destinasi wisata Pura Taman Ayun (Y2) adalah 0.117. Koefisien tersebut bertanda negatif, sehingga dapat dinyatakan semakin banyak kebijakan-kebijakan yang dikeluarkan oleh Pemerintah, tidak dapat meningkatkan kualitas destinasi wisata Pura Taman Ayun. Hal ini sejalan dengan penelitian yang dilakukan oleh Techera (20017) yang menyimpulkan bahwa kebijakan pemerintah kurang mendukung pembentukan destinasi wisata, salah satu sebabnya adalah adanya mutasi staf yang sudah berkompeten di bidangnya.

4. Besarnya koesifien estimate dari partisipasi masyarakat (X2) terhadap kualitas destinasi wisata Pura Taman Ayun (Y2) adalah 0.015. Koefisien tersebut bertanda negatif, sehingga dapat dinyatakan apabila partisipasi masyarakat (X2) semakin ditingkatkan maka semakin menurunkan kualitas destinasi wisata Pura Taman Ayun (Y2). Kesimpulan penelitian ini juga 
didukung oleh penelitian yang dilakukan oleh Tosun (2000) yang menyatakan bahwa partisipasi masyarakat di negara-negara berkembang masih belum optimal yang dicirikan dengan masih minimnya partisipasi masyarakat yang bersifat autentik (autenthic participation). Penelitian yang dilakukan oleh Heny (2013) juga menyimpulkan bahwa apabila peran pemerintah terlalu dominan dalam pengembangan sebuah destinasi wisata, maka akan dapat membatasi akses terhadap masyarakat untuk ikut berpartisipasi.

5. Besarnya koesifien estimate dari kewirausahaan (Y1) terhadap kualitas destinasi wisata Pura Taman Ayun (Y2) adalah 0.742. Koefisien tersebut bertanda positif yang apabila jiwa kewirausahaan (Y1) semakin ditingkatkan maka semakin tinggi pula kualitas destinasi wisata Pura Taman Ayun (Y2).. Hal ini sesuai dengan penelitian yang dilakukan oleh Dumasari dan Watemin (2013) serta penelitian Dinata dkk (2011), dimana seiring dengan makin meningkatnya jiwa kewirausahaan maka semakin besar pula peluang masyarakat untuk memasuki pasar industri pada destinasi wisata bersangkutan. Bahwa pada pelayanan pariwisata memerlukan kualitas pelayanan, sehingga prilaku kewirausahawanan akan mendukung terbentuknya inovasi pelayanan atas produk produk baru yang dapat disajikan oleh masyarakat setempat.

6. Penelusuran terhadap pengaruh tidak langsung dari kebijakan pemerintah (X1) terhadap kualitas destinasi wisata Pura Taman Ayun (Y2) melalui kewirausahaan (Y1) adalah signifikan berdasarkan tingkat kepercayaan 5\%, 
dengan nilai $\mathrm{t}=2.640$ yang ternyata masih lebih besar dibandingkan dengan tabel $\mathrm{t}=$ 1.996. Sehubungan dengan pengaruh langsung dari kebijakan pemerintah terhadap kualitas destinasi wisata Pura Taman Ayun adalah tidak signifikan, maka model relasi mediasi yang didapatkan adalah full mediation ( Hair, et. al, 2010) dan Nitz et. al., (2012). Penelitian ini searah dengan temuan King dan Whitelaw (1992) yang menyimpulkan bahwa penerapan kebijakan dengan memberikan peluang kepada pengusaha lokal untuk berinvestasi akan mampu untuk mendorong semakin banyaknya masyarakat lokal untuk berwirausaha/membuka lapangan kerja baru sehingga akan membantu meningkatkan kesejahteraannya. Dengan meningkatnya kesejahteraan maka secara langsung akan membuat masyarakat menjadi sadar bahwa keberadaan suatu destinasi wisata di wilayahnya sangat penting untuk dijaga dan dilestarikan.

7. Penelusuran terhadap pengaruh tidak langsung dari partisipasi masyarakat (X2) terhadap kualitas destinasi wisata Pura Taman Ayun (Y2) melalui kewirausahaan (Y1) adalah signifikan berdasarkan tingkat kepercayaan 5\%, dengan nilai $t=4.065$ yang ternyata masih lebih besar dibandingkan dengan tabel $\mathrm{t}=1.996$. Sehubungan dengan pengaruh langsung dari partisipasi masyarakat (X2) terhadap kualitas destinasi wisata Pura Taman Ayun (Y2) adalah tidak signifikan, maka model relasi mediasi yang didapatkan adalah full mediation ( Hair, et. al, 2010) dan (Nitz et. al 2012). Hasil ini sejalan dengan penelitian yang dilakukan oleh Mardi (2003) mengungkapkan bahwa partisipasi masyarakat dalam menjaga kelestarian alam dan keberlanjutan 
destinasi wisata akan terwujud apabila masyarakat lokal memperoleh peningkatan pendapatan. Masyarakat lokal akan menjadi lebih peduli terhadap kebersihan lingkungan serta kelestarian alam sekitar wilayah destinasi

\section{KESIMPULAN DAN SARAN}

Bahwa kebijakan-kebijakan yang dikeluarkan oleh pemerintah yang dipersepsikan oleh responden belum mampu dalam meningkatkan kualitas destinasi wisata Pura Taman Ayun. Keberadaan destinasi wisata Pura Taman Ayun juga ternyata kurang dapat memberikan akses terhadap masyarakat lokal untuk ikut secara langsung berpartisipasi. Hal ini juga sejalan dengan. Peningkatan kualitas destinasi wisata Pura Taman Ayun akan menjadi maksimal apabila masyarakat lokal diberi akses untuk ikut serta berpartisipasi melalui pembentukan usaha-usaha baru, sehingga masyarakat akan mendapatkan benefit ekonomi serta memperoleh peningkatan pendapatan yang akan membantu peningkatan kesejahteraannya sehingga akan membuat Selanjutnya masyarakat akan menjadi merasa bertanggung jawab dan ikut serta dalam menjaga keamanan, keasrian, kelestarian, kebersihan lingkungan serta keberlanjutan destinasi wisata Pura Taman Ayun.

\section{REFERENSI}

Cooper, et al., 1995, Tourism Principles and Practice, England: pearson education limited edinburg Gate Harlow Essex CM20JE.

Damanik, Janianton dan Weber, Helmut. (2006). Perencanaan Ekowisata Dari Teori ke Aplikasi. Yogyakarta: PUSPAR UGM dan Andi.

Hall, C. M. and Williams, A. M. 2008 Tourism and Innovation: Contemporary Geographies of Leisure, Tourism and Mobility. Abingdon: Routledge 
Hardy, A. L. \& Beeton, R. J. S. (2001). Sustainable Tourism or Manageable Tourism: Managing Resources for more than average outcomes. Journal of Sustainable Tourism.

Holloway, J. Christopher. 1985. The Business of Tourism. MacDonald and Evans

Jeffrey G. Covina, Dennis P. Slevin, 2011. Aligning strategic processes in pursuit of firm growth. Journal of Business Research. Volume 64, Issue 5

Karyono, A. Hari. 1997. Kepariwisataan. Jakarta : Penerbit PT. Gramedia Widiasarana Indonesia.

Larsen, P. \& A. Lewis. 2007. "How Award Winning SMEs Manage The Barriers to Innovation", Journal Creativity and Innovation Management.

Leiper. 1995. Tourism Management. Melbourne: RMIT.

Marpaung, Happy. (2002). Pengetahuan Kepariwisataan. Bandung; Alfabeta

Mbaiwa JE. 2004. The Social Economic Benefits and Challenges of a Community Based Safari Hunting Tourism in the Okavango Delta, Botswana. The Journal of Tourism Studies 15:41-44

Miller. D. 1983. The Correlates of Entrepreneurship in Three Types of Firm, Management Sciene

Mowforth, M \& Munt, I 2009, Tourism and sustainability: development and new tourism in the Third World, 3rd edn, Routledge, London

Mustar, P \& Laredo, P 2001, Innovation and research policy in France (19802000) or the disappearance of the Colbertist state.

Neto, Frederico., 2003, A New Approach to Sustainable Tourism Development: Moving Beyond Environmental Protection. Desa Discussion Paper, no. 29, United Nations.

Timothy, D. J. (2004). "Tourism and Community Development Issues". In R. Sharpley \& D. J. Telfer (eds), Tourism and Development, Concepts and Issues. Clevedon, Buffalo, Toronto, Sydney: Channel

Tosun, Cevat. 2000. "Limits to Community Participation in the Tourism Development Process in Developing Countries". Tourism Management. 